\title{
Soil Organic Carbon Pool under Diverse Chemical Fertilizer Management in Huang-Huai-Hai Plains, China
}

\author{
Xiangbin Kong $\cdot$ Baoguo Li $\cdot$ Rattan Lal $\cdot$ \\ Kejiang Li • Youlu Bai
}

Received: 23 August 2012/Accepted: 29 January 2013/Published online: 22 February 2013

(C) NAAS (National Academy of Agricultural Sciences) 2013

\begin{abstract}
Soil analyses for 0-20 cm depth were conducted to assess changes in soil organic carbon (SOC) pool under long-term experiments conducted from 1979 to 2005 at eight sites in the Huang-Huai-Hai plains (HHH) of China. Different treatments were grouped into seven categories: (i) no chemical fertilizer as the control treatment (CK); (ii) chemical nitrogen (N); (iii) phosphorus (P); (iv) combined application of chemical fertilizer $\mathrm{N}$ and $\mathrm{P}(\mathrm{NP})$; (v) combined application of chemical fertilizer phosphorus $(\mathrm{P})$ and potassium $(\mathrm{K})(\mathrm{PK})$; (vi) Integrated chemical fertilizer $\mathrm{N}$, $\mathrm{P}$, and $\mathrm{K}$ management (NPK); and (vii) combined application of chemical fertilizer $\mathrm{N}$ and $\mathrm{K}$ (NK). The data indicated the following: (i) The magnitude of mean SOC pool value for N, P, NP, NK, PK, NPK, and CK was 20.4 $\pm 1.8,20.1 \pm 1.7,20.3 \pm 2.0$, $20.3 \pm 1.1,19.5 \pm 0.8,21.2 \pm 1.2$, and $18.9 \pm 1.8 \mathrm{Mg} \mathrm{ha}^{-1}$, respectively. (ii) Compared with $\mathrm{CK}$, change in SOC pool was in the order of NPK $>\mathrm{NP}>\mathrm{N}$ for the same application rate of $\mathrm{N}$ chemical fertilizer. (iii) In comparison with the baseline, the SOC pool increased with an increase in the rate of chemical fertilizer use. (iv) The average rate of change in SOC pool $\left(\mathrm{kg} \mathrm{ha}^{-1}\right.$ year $\left.{ }^{-1}\right)$ was -250.0 to 270 , and the stable or steady rate of change was -253 to 142 . (v) The threshold rate $\left(\mathrm{kg} \mathrm{ha}^{-1}\right)$ of chemical fertilizers for increasing the SOC pool in the HHH was 270 for N, 150 for P, and 150 for K.
\end{abstract}

Keywords Soil C dynamic $\cdot$ Chemical fertilizer management $\cdot$ Diverse $\cdot$ Long-term experiments $\cdot$ China

\begin{abstract}
Abbreviations
SOC: Soil organic carbon; SNSS: Second National Soil Survey of China; C: Carbon; GHGs: Greenhouse gases;

CK: Control treatment; N: Chemical nitrogen; P: Phosphorus; K: Potassium; DNDC: Denitrification-decomposition; HHH: Huang-Huai-Hai plains;
\end{abstract}

\author{
X. Kong $(\bowtie) \cdot$ B. Li \\ The College of Resources and Environmental Science, \\ China Agricultural University, Beijing 100193, China \\ e-mail: kongxiangbin001@126.com \\ R. Lal \\ Carbon Management and Sequestration Center, The Ohio State \\ University, Columbus, OH 43210, USA

\section{K. Li} \\ Institute of Dryland Farming, Key Field Scientific Observation \\ Station of Hengshui Fluvo-aquic Soil Ecology Environment, \\ Ministry of Agriculture, Hengshui 053000, China

\section{Y. Bai} \\ Ministry of Agriculture Key Laboratory of Crop Nutrition \\ and Fertilization/Institute of Agricultural Resources \\ and Regional Planning, Chinese Academy of Agricultural \\ Sciences, Beijing 100081, China
}

\section{Introduction}

Carbon (C) storage and sequestration in agricultural soils is an important issue in the study of terrestrial carbon $\mathrm{C}$ and global climatic change [21]. China is the world's most populous country and a major emitter of greenhouse gases (GHGs) [31]. It is currently facing the dilemma of climate change mitigation caused by a strong increase in GHG emissions due to a rapid industrialization [19], and the increasing food demands to feed $22 \%$ of the world's population with merely only $7 \%$ of the world's arable land area. Thus, identification of accurate calculation of soil organic carbon (SOC) pool sequestration potential at region scale in China is the basis to solve this dilemma.

Some research has been conducted at field, regional, and national scales in China to estimate SOC pool, and the 
potential of SOC sequestration in arable lands [3,5]. Based on the total area of soils of China of $9.281 \times 10^{6} \mathrm{~km}^{2}$ from the Second National Soil Survey (SNSS) conducted by the Ministry of Agriculture SNSS data of the 1980s, Yu et al. [41] estimated the total SOC pool at $89.14 \mathrm{Pg}\left(1 \mathrm{Pg}=10^{15} \mathrm{~g}\right)$ and a mean SOC density of $96.0 \mathrm{Mg} \mathrm{C} \mathrm{ha}^{-1}$. Li et al. [25] estimated that the total SOC and soil inorganic $\mathrm{C}$ (SIC) pools in China to 1-m depth were 382.1 Pg. Huang et al. [13] estimated increase in China's SOC pool by 311-401 Tg year ${ }^{-1}$ using the data from 132 published papers in China. Piao et al. [31] estimated a net sink of $0.19-0.26 \mathrm{Pg} \mathrm{C}_{\text {year }}{ }^{-1}$ in terrestrial ecosystems of China during 1980s and 1990s. Yu et al. [40] estimated the SOC pool in Mollisols at 646.2 Tg C and the potential sequestration of $2,887.8 \mathrm{~kg} \mathrm{ha}^{-1}$. All the research computed these estimates on the basis of biomass, soil $\mathrm{C}$ inventories in the past, or for a range of management including conservational and conventional tillage, not on the basis of the rate of SOC pool in crop land. However, the accomplishment of the China's food security has strongly been affected by agricultural intensification especially through application of high rates of the chemical fertilizers.

The effects of diversity fertilizer managements at region scale are very important to accurate calculation of SOC pool in China. There are also attempts to estimate the SOC pool in relation to the rate of fertilizer use on arable lands in China. Some studies have estimated the SOC pool on the basis of the rate of change of SOC pool using the data from published papers about the antecedent and finial values under long-term experimental sites [27, 32, 37]. Wang et al. [36] reported that SOC increased over time with use of fertilizer, and relative annual change ( $\mathrm{RAC}, \mathrm{g} \mathrm{kg}^{-1}$ year ${ }^{-1}$ ) ranged from -0.14 to 0.60 ( 0.13 on average) for dry cropland soils, and from -0.12 to 0.70 ( 0.19 on average) for paddy rice soils. Using the denitrification-decomposition (DNDC) model and different fertilizer scenarios, Wang et al. [35] estimated change in SOC pool over 20 years by $-1,000$ to $200 \mathrm{~kg} \mathrm{C} \mathrm{ha}^{-1}$ year $^{-1}$ in northern China, compared with the only -70 to $26 \mathrm{~kg} \mathrm{C}^{-1}$ year $^{-1}$ in southern China. Pan et al. [29] estimated the increase in SOC pool by $0.3 \mathrm{Pg}$ in irrigated paddy rice soils of China compared with that in soil under crop land condition. Lu et al. [27] reported that the present rate of $\mathrm{N}$ fertilizer use in China can sequester $\sim 6 \mathrm{Tg} \mathrm{C}$ year $^{-1}$ with a potential of 12.1 $\mathrm{Tg} \mathrm{C}$ year $^{-1}$ through adoption of recommended management practices (RMPs). However, there are significant variations in the rate of SOC sequestration $[15,20]$, which might also be considered. These variations are attributable to the experimental duration and diverse fertilizer management [17], and numerous soil and site-scale factors. Thus, estimating SOC pool with due consideration to the fertilizer management in different soil types at region scale is important to identify the technological options for sustainable management.
Based on the paired data from 137 sites with varying $\mathrm{N}$ rates and 161 sites with contrasting tillage systems, Alvarez [1] reported strong effects of soil and climatic factors. Several long-term studies have indicated the positive response of SOC pool to fertilizer use [14, 16, 27, 43]. Cai and Qin [2] reported a significant but a logarithmic relationship between roots and compost input and SOC concentration, and concluded that the SOC pool in $0-20 \mathrm{~cm}$ depth decreased by $1.6 \mathrm{Mg} \mathrm{C}^{-1}$ in NK treatment in the HHH. Ma et al. [28] reported that combined use of inorganic fertilizer and manure can significantly increase the SOC pool compared with the unfertilized control. The data from a long-term field experiment in Fengqiu showed that the rate of change in SOC pool depends on the kind of fertilizer, application of balanced or unbalanced chemical fertilizers, the rate of fertilizer applied in the antecedent SOC pool, and the duration of fertilizer use [8]. However, there is a lack of data based on systematic and long-term studies on change in SOC pool in response to diverse fertilizer management practices at region scale in China.

The Huang-Huai-Hai plains $(\mathrm{HHH})$ is the primary wheat (Triticum aestivum)-maize (Zea mays) cultivation area in China. It comprises $\sim 16 \%$ of China's cropland [12, 24], accounts for $>40 \%$ of China's wheat production, and supports a large farming population [11]. A series of longterm experimental sites were initiated in 1979 to assess the effects of fertilizer management on the crop yield and SOM concentration. The hypothesis of this article is that the increase in SOC pool in HHH region has been strongly affected by different fertilization, thus the effects of diversity fertilizer managements give the scientific basis to accurately calculate SOC pool in the HHH region. Therefore, the objective of this study is to assess the long-term effects of diverse fertilizer management practices on the SOC pool and sequestration rate in the $\mathrm{HHH}$ of China.

\section{Materials and Methods}

\section{Study Area}

The HHH plains, located in northern China, are formed by alluvial sediments deposited by three rivers (i.e., the Huang River or Yellow River, Huai River, and Hai River) (Fig. 1). These are the largest plains and constitute an important agricultural region in China, covering $320,000 \mathrm{~km}^{2}$, with 18.67 million ha ( $\mathrm{M} \mathrm{ha}$ ) of farmland and a population of 200 million [6]. The region is characterized by intensive use of irrigation and chemical fertilizers, and the predominant cropping system in the region is double-cropping of winter wheat and summer maize. The SOC concentration was measured for soils from different long-term experimental sites in the HHH (Fig. 1). 
Climate and soil properties of sites are shown in Table 1. The annual rainfall ranges from 461.9 to $837.3 \mathrm{~mm}$, the annual accumulative temperature from $4,874.0$ to 5,368.2 degree days, and the annual average temperature from 12.8 to $14.6{ }^{\circ} \mathrm{C}$ [12].

\section{Treatment and Sites}

Eight control and twenty-eight different chemical fertilizer treatments at eight experimental sites in the $\mathrm{HHH}$ were grouped into 7 categories (Table 2) as follows: (i) no chemical fertilizer as the control treatment (CK); (ii) chemical nitrogen $(\mathrm{N})$; (iii) phosphorus (P); (iv) combined application of chemical fertilizer $\mathrm{N}$ and $\mathrm{P}$ (NP); (v) combined application of chemical fertilizer phosphorus $(\mathrm{P})$ and potassium $(\mathrm{K})(\mathrm{PK})$; (vi) integrated chemical fertilizer $\mathrm{N}, \mathrm{P}$, and $\mathrm{K}$ management (NPK); and (vii) combined application of chemical fertilizer $\mathrm{N}$ and $\mathrm{K}(\mathrm{NK})$. The chemical fertilizer application rates in the $\mathrm{HHH}$ consists of 8 rates of $\mathrm{N}$ at 90(N1), 135(N2), 180(N3), 240(N4), 270(N5), 300(N6), $330(\mathrm{~N} 7)$, and $360(\mathrm{~N} 8) \mathrm{kg} \mathrm{ha}^{-1} ; 7$ rates of $\mathrm{P}$ at $60(\mathrm{P} 1)$, 67.5(P2), 82.5(P3), 120(P4), 135(P5), 150(P6), and 180 (P7) $\mathrm{kg} \mathrm{ha}^{-1}$, and 5 rates $\mathrm{K}$ at 82.5(K1), 120(K2), 150(K3),

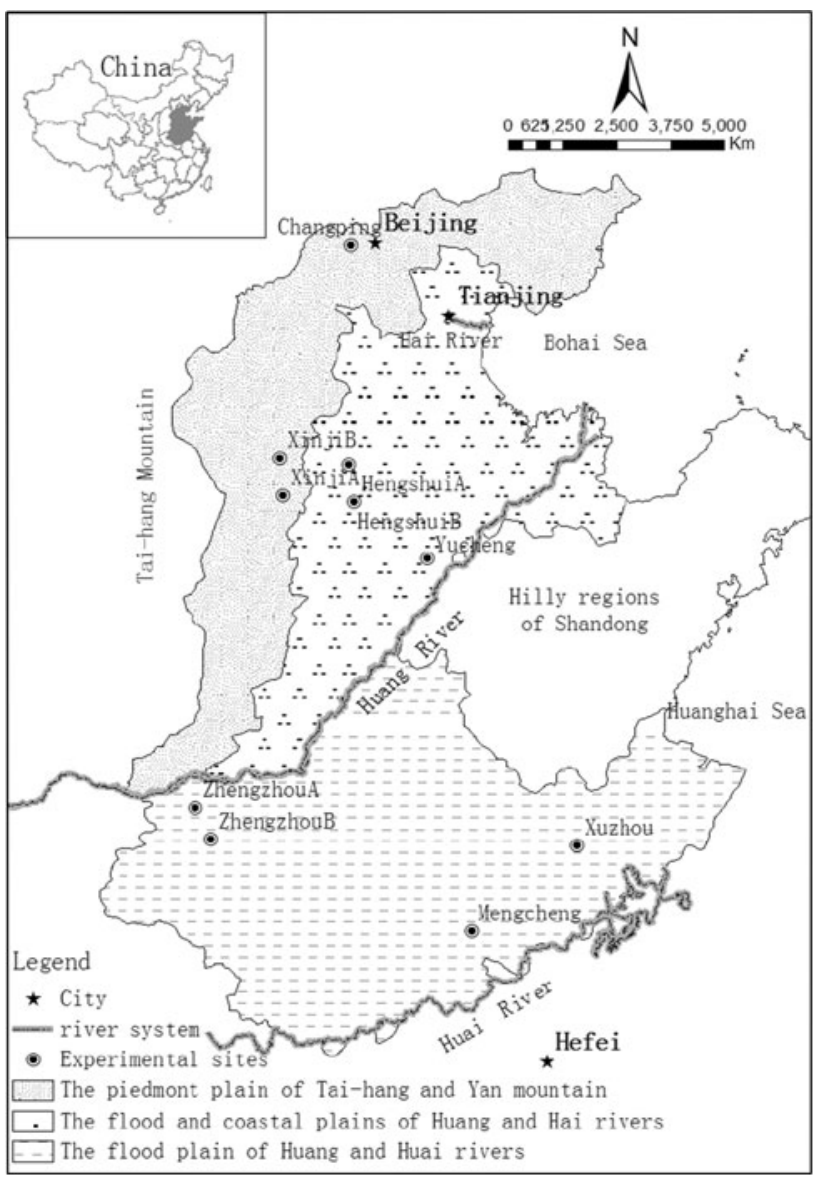

Fig. 1 Location of eight long-term experimental sites
225(K4), and $250(\mathrm{~K} 5) \mathrm{kg} \mathrm{ha}^{-1}$. The specific fertilizer treatment was uniform numbered, according to the rate of application fertilizer at 8 sites (Table 2).

Winter wheat was irrigated 2-3 times and maize 1-2 times depending on the precipitation. The volume of water used for each of irrigation was $900 \mathrm{~m}^{3} \mathrm{ha}^{-1}(9 \mathrm{~cm})$ to 1,200 $(12 \mathrm{~cm}) \mathrm{m}^{3} \mathrm{ha}^{-1}$. Herbicides and pesticides were applied to control weeds and reduce the insect pressure, respectively. Organic and chemical fertilizers including $\mathrm{P}$, $\mathrm{K}$ were applied as basal dose, 1/3-2/3 part of $\mathrm{N}$ was applied as basal dose and the other part as top dressing for wheat. All the chemical fertilizers were top dressed for maize.

\section{Soil Sampling and Analysis}

Experimental plots varied from 1 to 3 for every treatment across the long-term experiments. However, the plot area varied from 40 to $100 \mathrm{~m}^{2}$ [9, 26, 38, 39, 42, 44]. Soil samples for assessing the SOC concentration were obtained from 0 to $20 \mathrm{~cm}$ depth for all sites before the harvest of wheat every year between 1980 and 2003. There soil samples were selected to analyze SOC concentration. The SOC concentration was determined by the wet combustion method [34], bulk density by the core method [33], and texture by the hydrometer method [7]. Soil texture ranged from silty clay loam, loam, silt loam to loam. The data on SOC concentration were normalized and converted to SOC pool [25] using Eq. 1:

$$
\begin{aligned}
\operatorname{SOC} \text { pool }\left(\mathrm{Mg} \mathrm{ha}^{-1}\right)= & \operatorname{SOC}\left(\mathrm{g} \mathrm{kg}^{-1}\right) \times 10^{4} \mathrm{~m}^{2} \mathrm{ha}^{-1} \\
& \times 0.2 \mathrm{~m} \times \operatorname{SBD}\left(\mathrm{Mg} \mathrm{m}^{-3}\right) \times 10^{-3}
\end{aligned}
$$

where SOC concentration is in $\mathrm{g} \mathrm{kg}^{-1}$, and soil bulk density (SBD) is in $\mathrm{Mg} \mathrm{m}^{-3}$, change in SOC pool in treatments was computed with reference to the control (CK) using Eqs. 2 and 3:

$$
\begin{aligned}
& \operatorname{SOC}_{\mathrm{TR}}\left(\mathrm{Mgha}^{-1}\right)=\operatorname{Tr}\left(\mathrm{Mgha}^{-1}\right)-\operatorname{CK}\left(\mathrm{Mgha}^{-1}\right) \\
& \operatorname{SOC}_{\mathrm{TI}}\left(\mathrm{Mgha}^{-1}\right)=\operatorname{Tr}\left(\mathrm{Mgha}^{-1}\right)-\mathrm{SOC}_{\mathrm{i}}\left(\mathrm{Mgha}^{-1}\right)
\end{aligned}
$$

where $\mathrm{SOC}_{\mathrm{TR}}$ is the change in SOC pool under specific treatment (TR) in comparison with that under $\mathrm{CK}$. $\mathrm{SOC}_{\mathrm{TR}}$ is the net change in SOC pool. Thus, all the SOC in different fertilizer treatments can be compared with each other across the $\mathrm{HHH}$.

$\mathrm{SOC}_{\mathrm{TI}}$ is the change in SOC pool during the experimental period under different treatments in comparison with the antecedent $\mathrm{SOC}_{\mathrm{i}}$ value (soil organic carbon for the first 3 years during long-term experiments).

The steady state rate (SR) and average rate (AR) of SOC change were calculated using Eqs. 3 and 4:

$\operatorname{AR}\left(\mathrm{kg} \mathrm{ha}^{-1}\right.$ year $\left.^{-1}\right)=\left(\mathrm{SOC}_{\mathrm{f}}-\mathrm{SOC}_{\mathrm{i}}\right) / t$ 
Table 1 Soil and climate environments of the 8 long-term experimental sites in the $\mathrm{HHH}$

\begin{tabular}{|c|c|c|c|c|c|c|c|c|c|}
\hline \multirow{2}{*}{$\begin{array}{l}\text { Sites } \\
\text { County }\end{array}$} & \multicolumn{2}{|l|}{ Region } & \multirow{2}{*}{$\begin{array}{l}\text { Annual rainfall } \\
\text { mm year }^{-1}\end{array}$} & \multirow{2}{*}{$\begin{array}{l}\text { Annual } \\
\text { cumulative } \\
\text { temperature } \\
{ }^{\circ} \mathrm{C} . \mathrm{d}\end{array}$} & \multirow{2}{*}{$\begin{array}{l}\text { Annual } \\
\text { average } \\
\text { temperature } \\
{ }^{\circ} \mathrm{C}\end{array}$} & \multirow[t]{2}{*}{ Experiment term } & \multirow[t]{2}{*}{$\mathrm{pH}$} & \multirow[t]{2}{*}{ Soil texture } & \multirow{2}{*}{$\begin{array}{l}\text { Bulk density } \\
\mathrm{gcm}^{-3}\end{array}$} \\
\hline & Latitude & Longitude & & & & & & & \\
\hline Chang ping & $40^{\circ} 02^{\prime}$ & $116^{\circ} 10^{\prime}$ & 574.1 & 4874 & 12.78 & 1984-1997 & 8.6 & Silty clay Loam & 1.45 \\
\hline Henshui A & $37^{\circ} 42^{\prime}$ & $115^{\circ} 42^{\prime}$ & 478.1 & 4996.3 & 13.19 & 1979-2002 & 8.32 & Loam & 1.39 \\
\hline Henshui B & $37^{\circ} 43^{\prime}$ & $115^{\circ} 43^{\prime}$ & 478.1 & $4,996.3$ & 13.19 & 1979-2002 & 8.24 & Loam & 1.45 \\
\hline Xinji A & $37^{\circ} 54^{\prime}$ & $115^{\circ} 13^{\prime}$ & 461.9 & $5,015.7$ & 13.24 & 1979-1999 & 8.26 & Silt loam & 1.40 \\
\hline Xinji B & $37^{\circ} 55^{\prime}$ & $115^{\circ} 14^{\prime}$ & 461.9 & $5,015.7$ & 13.24 & 1979-1999 & 8.2 & Silt loam & 1.40 \\
\hline Zhenzhou A & $34^{\circ} 46^{\prime}$ & $113^{\circ} 40^{\prime}$ & 623.2 & $5,334.0$ & 14.35 & 1980-2000 & 8.1 & Loam & 1.48 \\
\hline Zhenzhou B & $34^{\circ} 47^{\prime}$ & $113^{\circ} 41^{\prime}$ & 623.2 & $5,334.0$ & 14.35 & 1990-1999 & 8.3 & Loam & 1.48 \\
\hline Xuzhou & $33^{\circ} 54^{\prime}$ & $117^{\circ} 57^{\prime}$ & 837.3 & $5,368.2$ & 14.62 & 1980-1987 & 8.25 & Sand loam & 1.40 \\
\hline
\end{tabular}

$\mathrm{SR}\left(\mathrm{kg} \mathrm{ha}^{-1}\right.$ year $\left.^{-1}\right)=\left(\mathrm{SOC}_{\mathrm{s}}-\mathrm{SOC}_{\mathrm{i}}\right) / t$

where $\mathrm{SOC}_{\mathrm{i}}$ is $\mathrm{SOC}$ pool at the onset of the experiment and $\mathrm{SOC}_{\mathrm{f}}$ is the final SOC pool after $t$ years of experiment, $\mathrm{SOC}_{\mathrm{s}}$ is the steady (mean) state of SOC pool during the experimental period.

\section{Data Processing and Statistical Analysis}

Data were organized into 36 different sub-treatments according to the rate of application of $\mathrm{N}, \mathrm{P}$, and $\mathrm{K}$ among eight long-term experimental sites. The data of SOC pool for all the treatments were computed for mean and standard deviation $(\overline{\mathrm{X}} \pm \overline{\mathrm{SD}})$. The SOC trend line for different treatments was computed using Microsoft Excel 2007. Figures and tables in this manuscript were formulated based on the different combinations of application rate of $\mathrm{N}, \mathrm{P}$, and $\mathrm{K}$. Significance of differences at $P<0.05$ and $P<0.01$ among treatments in different long-term experiment sites was tested using the SPSS (Version 13.0).

\section{Results and Discussion}

SOC Pool under Diverse Chemical Fertilizer

Managements Across HHH

Statistical analyses of 465 data from 36 different treatments at eight long-term experiential sites are shown in Table 3. The mean SOC pool in 0-20 cm depth for N, P, NP, NK, PK, NPK, and CK categories was $20.4 \pm 1.8,20.1 \pm 1.7$, $20.3 \pm 2.0, \quad 20.3 \pm 1.1, \quad 19.5 \pm 0.8, \quad 21.2 \pm 1.2$, and $18.9 \pm 1.8 \mathrm{Mg} \mathrm{ha}^{-1}$, respectively. The SOC pool for N, P, NP, NK, and NPK land use and managements differed significantly from that of CK; that for N, NP, NPK from that of PK management; and that for N, NP, P, NP, PK from that of NPK treatments. The maximum SOC pool was observed for the NPK, and the least for the CK treatment. The SOC pool was in the order of NPK $>\mathrm{N}>\mathrm{NP}>\mathrm{NK}>$ $\mathrm{P}>\mathrm{PK}>\mathrm{CK}$. The trend of change in SOC pool for different categories showed that the $\mathrm{N}$ fertilization management strongly influenced SOC sequestration potential in the HHH. The data presented indicated that SOC pool can be increased by increasing the application rates of $\mathrm{N}$ fertilizer.

Statistical analysis of 64 datasets for N, 39 for P, 178 for NP, 8 for NK, 8 for PK, 58 for NPK, and 110 SOC pool data for $\mathrm{CK}$ treatments among eight long-term experiential sites is shown in Fig. 2. The SOC pool in Xuzhou site differed significantly from that in other seven sites for the CK treatment. The SOC pool in different sites ranged from $15.6 \pm 1.1$ to $20.6 \pm 1.4 \mathrm{Mg} \mathrm{ha}^{-1}$ across the HHH. The maximum value of SOC pool was $20.6 \pm 1.4 \mathrm{Mg} \mathrm{ha}^{-1}$ in ZhengzhouA, and the least of $15.6 \pm 1.1 \mathrm{Mg} \mathrm{ha}^{-1}$ for the Xuzhou site. The mean SOC pool for CK was $18.9 \pm$ $1.8 \mathrm{Mg} \mathrm{ha}^{-1}$, which is the baseline value for arable land without any fertilizer input in 1980s in the HHH. The soil C sequestration (SCS) potential for different fertilizer management treatments can be computed with reference to the baseline SOC pool for cropland soils of the region.

The SOC pool in relation to $\mathrm{N}$ fertilizer management consists of 5 different treatments including application rates of $135,240,270,300$, and $330 \mathrm{~kg} \mathrm{ha}^{-1}$. The corresponding SOC pool ranged from $18.1 \pm 0.8$ to $21.7 \pm 0.8 \mathrm{Mg} \mathrm{ha}^{-1}$, with an average of $20.4 \pm 1.8 \mathrm{Mg} \mathrm{ha}^{-1}$. The SOC sequestration potential in croplands for different $\mathrm{N}$ fertilizer use in the HHH can be estimated using the baseline value for the CK management.

The SOC pool for NP fertilizer management consists of 13 different combined $\mathrm{N}$ and $\mathrm{P}$ fertilizer treatments with the application rates of $90,135,180,240,270,300,330$, and $360 \mathrm{~kg} \mathrm{ha}^{-1}$ for $\mathrm{N}$ fertilizer, and seven $\mathrm{P}$ fertilizer application 
Table 2 Chemical fertilizer rates in different treatments
The chemical fertilizer application rates in the $\mathrm{HHH}$ consist of 8 rates of $\mathrm{N}$ at 90(N1), 135(N2), 180(N3), 240(N4), 270(N5), 300(N6), $330(\mathrm{~N} 7)$, and 360(N8) $\mathrm{kg} \mathrm{ha}^{-1}$; 7 rates of $\mathrm{P}$ at $60(\mathrm{P} 1), 67.5(\mathrm{P} 2)$, 82.5(P3), 120(P4), 135(P5), 150(P6), and 180(P7) $\mathrm{kg} \mathrm{ha}^{-1}$, and 5 rates $\mathrm{K}$ at $82.5(\mathrm{~K} 1)$, 120(K2), 150(K3), 225(k4), and $250(\mathrm{k} 5) \mathrm{kg} \mathrm{ha}^{-1}$

\begin{tabular}{|c|c|c|c|c|c|c|}
\hline \multirow[t]{2}{*}{ Sites } & \multirow[t]{2}{*}{ Treatments } & \multirow[t]{2}{*}{ Classification } & \multirow[t]{2}{*}{ Original treatments } & \multicolumn{3}{|c|}{ Fertilizer input $\left(\mathrm{kg} \mathrm{ha}^{-1}\right)$} \\
\hline & & & & $\mathrm{N}$ & $\mathrm{P}_{2} \mathrm{O}_{5}$ & $\mathrm{~K}_{2} \mathrm{O}$ \\
\hline \multirow[t]{4}{*}{ XinjiA } & $\mathrm{CK}$ & $\mathrm{CK}$ & $\mathrm{CK}$ & 0 & 0 & 0 \\
\hline & N7 & $\mathrm{N}$ & $\mathrm{N}$ & 330 & 0 & 0 \\
\hline & N7P6 & NP & NP & 330 & 150 & 0 \\
\hline & P6 & $\mathrm{P}$ & $\mathrm{P}$ & 0 & 150 & 0 \\
\hline \multirow[t]{4}{*}{ XinjiB } & CK & CK & CK & 0 & 0 & 0 \\
\hline & N5 & $\mathrm{N}$ & $\mathrm{N}$ & 270 & 0 & 0 \\
\hline & N5P6 & NP & NP & 270 & 150 & 0 \\
\hline & N5P6K3 & NPK & NPK & 270 & 150 & 150 \\
\hline \multirow[t]{5}{*}{ Jiangsu } & CK & CK & CK & 0 & 0 & 0 \\
\hline & N6 & $\mathrm{N}$ & $\mathrm{N}$ & 300 & 0 & 0 \\
\hline & N6P6 & NP & NP & 300 & 150 & 0 \\
\hline & N6P6K5 & NPK & NPK & 300 & 150 & 250 \\
\hline & CK & CK & CK & 0 & 0 & 0 \\
\hline \multirow[t]{4}{*}{ ZhengzhuoA } & N4 & $\mathrm{N}$ & $\mathrm{N}$ & 240 & 0 & 0 \\
\hline & N4P4 & $\mathrm{NP}$ & NP & 240 & 120 & 0 \\
\hline & N4P4K2 & NPK & NPK & 240 & 120 & 120 \\
\hline & CK & CK & CK & 0 & 0 & 0 \\
\hline \multirow[t]{7}{*}{ ZhengzhuoB } & N7 & $\mathrm{N}$ & $\mathrm{N}$ & 330 & 0 & 0 \\
\hline & N7P3 & NP & NP & 330 & 82.5 & 0 \\
\hline & N7P3K1 & NPK & NPK & 330 & 82.5 & 82.5 \\
\hline & P3K1 & PK & PK & 0 & 82.5 & 82.5 \\
\hline & N7K1 & NK & NK & 330 & 0 & 82.5 \\
\hline & CK & CK & CK & 0 & 0 & 0 \\
\hline & $\mathrm{P} 2$ & $\mathrm{P}$ & $\mathrm{P} 1$ & 0 & 67.5 & 0 \\
\hline \multirow[t]{10}{*}{ Changpin } & P5 & $\mathrm{P}$ & $\mathrm{P} 2$ & 0 & 135 & 0 \\
\hline & $\mathrm{N} 2$ & $\mathrm{~N}$ & N1 & 135 & 0 & 0 \\
\hline & N5 & $\mathrm{N}$ & $\mathrm{N} 2$ & 270 & 0 & 0 \\
\hline & $\mathrm{N} 2 \mathrm{P} 2$ & $\mathrm{~N}$ & N1 & 135 & 67.5 & 0 \\
\hline & N2P5 & $\mathrm{N}$ & N1 & 135 & 135 & 0 \\
\hline & $\mathrm{N} 5 \mathrm{P} 2$ & NP & $\mathrm{N} 2 \mathrm{P} 1$ & 270 & 67.5 & 0 \\
\hline & N5P5 & NP & $\mathrm{N} 2 \mathrm{P} 2$ & 270 & 135 & 0 \\
\hline & N5P5K4 & NPK & $\mathrm{N} 2 \mathrm{P} 2 \mathrm{~K} 2$ & 270 & 135 & 225 \\
\hline & CK & CK & CK & 0 & 0 & 0 \\
\hline & $\mathrm{N} 1 \mathrm{P} 2$ & NP & NP & 90 & 67.5 & 0 \\
\hline Hengshui B & $\mathrm{N} 2 \mathrm{P} 1$ & NP & NP & 105 & 60 & 0 \\
\hline \multirow[t]{4}{*}{ HengshuiA } & CK & CK & CK & 0 & 0 & 0 \\
\hline & N1P1 & NP & N1P1 & 90 & 60 & 0 \\
\hline & N3P4 & NP & $\mathrm{N} 2 \mathrm{P} 2$ & 180 & 120 & 0 \\
\hline & N8P7 & NP & N3P3 & 360 & 180 & 0 \\
\hline
\end{tabular}

The SOC pool for NPK fertilizer management is based on 5 treatments, with application rates of 240, 270, 300, and $330 \mathrm{~kg} \mathrm{ha}^{-1}$ for $\mathrm{N}$ fertilizer; $82.5,120,135$, and $150 \mathrm{~kg} \mathrm{ha}^{-1}$ for Pfertilizer; and 82.5, 120, 150, 225, and $250 \mathrm{~kg} \mathrm{ha}^{-1}$ for K fertilizer. The SOC pool for 5 NPK fertilizer treatments ranged from $18.6 \pm 0.7$ to $23.3 \pm 1.4 \mathrm{Mg} \mathrm{ha}^{-1}$, with the maximum value of $23.3 \pm 1.4 \mathrm{Mg} \mathrm{ha}^{-1}$ in the $\mathrm{HHH}$ among all the fertilizer treatments. The SOC pool for other fertilizer 
Table 3 Statistical analysis of SOC pool under different treatments for 8 long-term experimental sites
The average of CK from 1 to 8 as CKt; the average of $\mathrm{N}$ for different rates as $\mathrm{Nt}$; the average of $\mathrm{P}$ for different rates as $\mathrm{Pt}$; the average of NP for different rates as NPt; the average of NPK for different rates as NPKt. The CK in different sites were definite as from CK1 to CK8. Mean followed by lower difference letter differ from one another at $5 \%$ level of probability for different treatments within the same categories, the capital difference letter for the different categories

\begin{tabular}{|c|c|c|c|c|c|c|c|}
\hline \multirow[t]{2}{*}{ Categories } & \multirow[t]{2}{*}{ Treatments } & \multirow[t]{2}{*}{$\mathrm{N}$} & \multirow{2}{*}{$\begin{array}{l}\mathrm{SOC} \\
\left(\mathrm{g} \mathrm{kg}^{-1}\right)\end{array}$} & \multirow{2}{*}{$\begin{array}{l}\text { Bulk density } \\
\left(\mathrm{gcm}^{-3}\right)\end{array}$} & \multicolumn{3}{|c|}{ SOC pool $\left(\mathrm{Mg} \mathrm{C} \mathrm{ha}^{-1}\right)$} \\
\hline & & & & & Mean & $\mathrm{SD}$ & $\mathrm{CV}(\%)$ \\
\hline \multirow[t]{9}{*}{ CK } & XinjiA & 15 & 6.57 & 1.40 & $18.4 \mathrm{c}$ & 2.0 & 10.6 \\
\hline & XinjiB & 13 & 6.86 & 1.40 & $19.2 \mathrm{~cd}$ & 0.9 & 4.8 \\
\hline & Xuzhou & 7 & 5.38 & 1.40 & $15.6 \mathrm{a}$ & 1.1 & 6.8 \\
\hline & Changping & 12 & 6.70 & 1.45 & 20.0de & 1.1 & 5.6 \\
\hline & ZhengzhuoA & 18 & 6.96 & 1.48 & $20.6 \mathrm{e}$ & 1.4 & 6.8 \\
\hline & ZhengzhuoB & 8 & 6.35 & 1.48 & $18.8 \mathrm{c}$ & 1.0 & 5.3 \\
\hline & HengshuiA & 16 & 6.22 & 1.39 & $17.3 \mathrm{~b}$ & 1.1 & 6.5 \\
\hline & Hengshui B & 21 & 6.59 & 1.45 & $19.1 \mathrm{~cd}$ & 1.0 & 5.1 \\
\hline & Total & 110 & & & $18.86 \mathrm{~A}$ & 1.8 & 9.5 \\
\hline \multirow[t]{6}{*}{$\mathrm{N}$} & $\mathrm{N} 2$ & 12 & 7.10 & 1.45 & $20.6 b$ & 1.3 & 6.4 \\
\hline & N4 & 18 & 7.33 & 1.48 & $21.7 \mathrm{c}$ & 0.8 & 3.8 \\
\hline & N5 & 12 & 7.64 & 1.40 & $21.4 \mathrm{bc}$ & 1.3 & 6.0 \\
\hline & N6 & 7 & 6.46 & 1.40 & $18.1 \mathrm{a}$ & 0.8 & 4.4 \\
\hline & N7 & 15 & 6.32 & 1.48 & $18.7 \mathrm{a}$ & 1.4 & 7.6 \\
\hline & Total & 64 & & & $20.4 \mathrm{BC}$ & 1.8 & 8.9 \\
\hline \multirow[t]{4}{*}{$\mathrm{P}$} & $\mathrm{P} 2$ & 12 & 7.07 & 1.45 & $20.5 b$ & 1.2 & 6.0 \\
\hline & P5 & 12 & 7.38 & 1.45 & $21.4 \mathrm{~b}$ & 0.9 & 4.2 \\
\hline & P6 & 15 & 6.71 & 1.40 & $18.8 \mathrm{a}$ & 1.7 & 9.0 \\
\hline & Total & 39 & & & $20.1 \mathrm{BC}$ & 1.7 & 8.6 \\
\hline \multirow[t]{14}{*}{ NP } & N1P1 & 16 & 6.62 & 1.39 & $18.4 \mathrm{ab}$ & 0.4 & 2.4 \\
\hline & $\mathrm{N} 1 \mathrm{P} 2$ & 21 & 7.34 & 1.39 & $20.4 \mathrm{c}$ & 1.2 & 5.9 \\
\hline & $\mathrm{N} 2 \mathrm{P} 2$ & 12 & 7.45 & 1.45 & $21.6 \mathrm{~d}$ & 1.2 & 5.4 \\
\hline & $\mathrm{N} 2 \mathrm{P} 5$ & 12 & 7.69 & 1.45 & $22.3 \mathrm{de}$ & 1.0 & 4.3 \\
\hline & $\mathrm{N} 3 \mathrm{P} 4$ & 16 & 6.73 & 1.39 & $18.7 \mathrm{~b}$ & 1.3 & 7.0 \\
\hline & N4P4 & 18 & 7.50 & 1.48 & $22.2 \mathrm{de}$ & 1.0 & 4.5 \\
\hline & N5P2 & 12 & 7.52 & 1.45 & $21.8 \mathrm{de}$ & 1.2 & 5.7 \\
\hline & N5P5 & 12 & 7.83 & 1.45 & $22.7 \mathrm{e}$ & 1.1 & 4.9 \\
\hline & N5P6 & 13 & 6.64 & 1.40 & $18.6 \mathrm{~b}$ & 1.4 & 7.6 \\
\hline & N6P6 & 7 & 6.25 & 1.40 & $17.5 \mathrm{a}$ & 1.0 & 5.4 \\
\hline & N7P3 & 8 & 7.20 & 1.48 & $21.3 \mathrm{~d}$ & 1.4 & 6.7 \\
\hline & N7P6 & 15 & 6.93 & 1.40 & $19.4 b$ & 1.9 & 9.9 \\
\hline & N8P7 & 16 & 6.80 & 1.39 & $18.9 \mathrm{~b}$ & 1.2 & 6.2 \\
\hline & Total & 178 & & & $20.27 \mathrm{BC}$ & 2.0 & 9.9 \\
\hline NK & N7K1 & 8 & 6.84 & 1.48 & $20.26 \mathrm{BC}$ & 1.1 & 5.3 \\
\hline PK & P3K1 & 8 & 6.58 & 1.48 & $19.49 \mathrm{AB}$ & 0.8 & 4.2 \\
\hline \multirow[t]{6}{*}{ NPK } & N4P4K2 & 18 & 7.64 & 1.48 & $22.6 \mathrm{c}$ & 0.9 & 4.2 \\
\hline & N5P5K4 & 12 & 8.03 & 1.45 & $23.3 \mathrm{c}$ & 1.4 & 6.0 \\
\hline & N5P6K3 & 13 & 7.07 & 1.40 & $19.8 \mathrm{~b}$ & 1.4 & 7.3 \\
\hline & N6P6K5 & 7 & 6.64 & 1.40 & $18.6 \mathrm{a}$ & 0.7 & 3.8 \\
\hline & N7P3K1 & 8 & 6.55 & 1.48 & $19.4 \mathrm{ab}$ & 1.9 & 9.6 \\
\hline & Total & 58 & & & $21.2 \mathrm{C}$ & 2.2 & 10.3 \\
\hline
\end{tabular}

treatments (i.e., P2, P5, P6, N7K1, and P3K1) ranged from $19.5 \pm 0.8$ to $20.3 \pm 1.1 \mathrm{Mg} \mathrm{ha}^{-1}$. The SCS rate was higher when $\mathrm{N}$ was used in combination with $\mathrm{P}$ and $\mathrm{K}$ than for those with application of either of these fertilizer alone.

The trends of change in SOC pool for N2, N4, N5, N6, and N7 treatments corresponding with NP and NPK fertilizers under different application rates of $\mathrm{N}$ fertilizer are shown in Fig. 3. The trend of change in SOC pool was in the order of N2P5 $>\mathrm{N} 2 \mathrm{P} 2>\mathrm{N} 2, \mathrm{~N} 4 \mathrm{P} 4 \mathrm{~K} 2>\mathrm{N} 4 \mathrm{P} 4>$ N4, N5P5K4 $>$ N5P5 $>$ N5, and N7P7 $>$ N7. The trends of change in SOC were in the order of NPK $>\mathrm{NP}>\mathrm{N}$ for the same application rates of $\mathrm{N}$ fertilizer. The SOC 

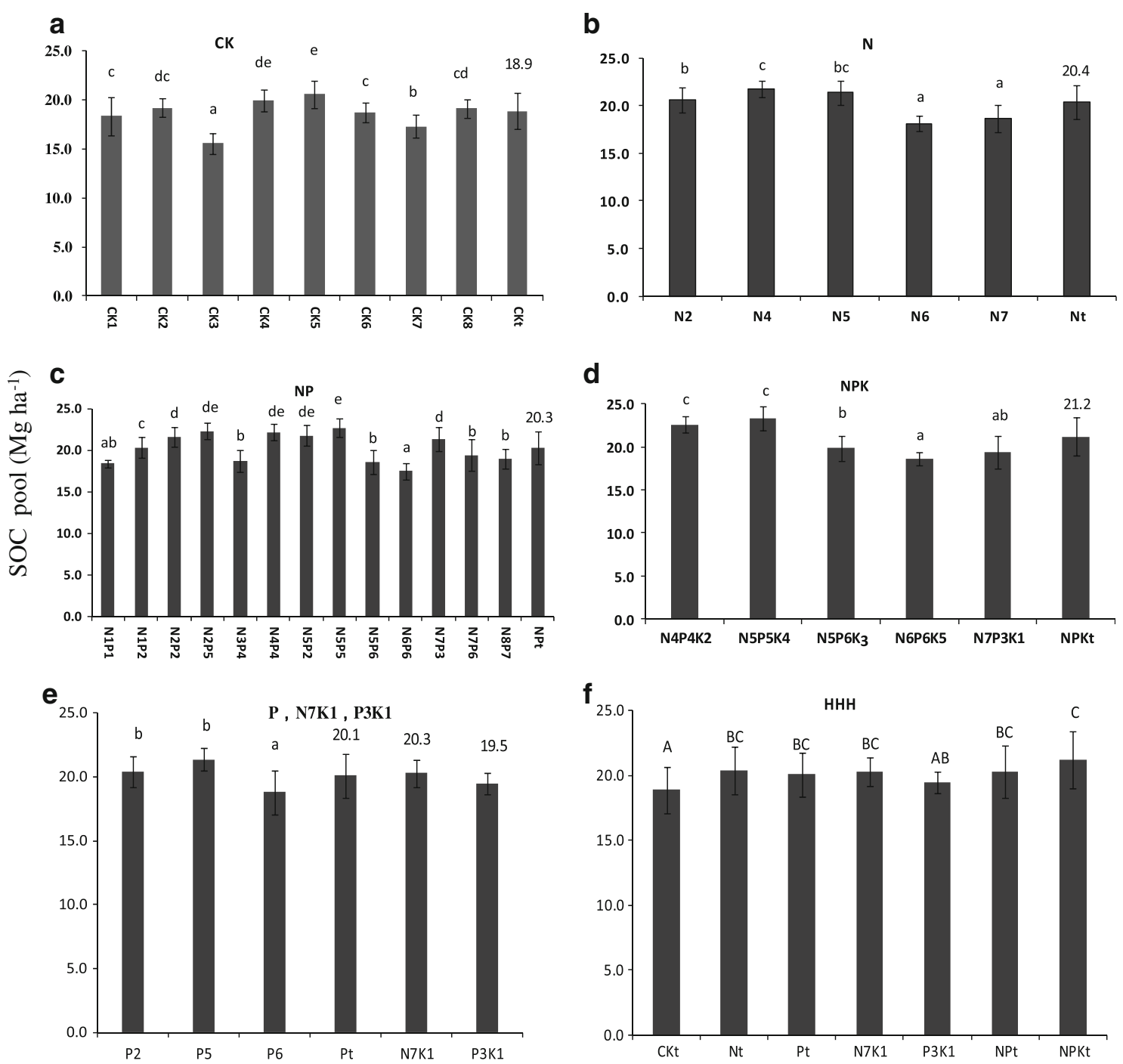

Fig. 2 The SOC pool in 0-20 $\mathrm{cm}$ depth for different treatments in the HHH. a Mean of SOC for CK treatments from 1 to 8 long-term experiments across the $\mathrm{HHH}$; $\mathrm{b}$. Mean of SOC for $\mathrm{N}$ treatments at different rates of $\mathrm{N}$ application across the $\mathrm{HHH}$; c. Mean of SOC for treatments at different rates of $\mathrm{N}$ combined with different rates of $\mathrm{P}$ application; d. Mean of SOC for treatments at combined N, P, K at different rates; e. Mean of SOC for treatments at different rates of $\mathrm{P}$

sequestration for the combined application of chemical fertilizers was higher than that for the application of $\mathrm{N}$ fertilizer.

The data based on 36 treatments represent the SOC response to diverse fertilizer management practices, and diversity of land uses and management in the HHH [18, 19]. The SOC sequestration potential for diverse fertilizer management can be calculated using the baseline SOC pool and the specific values for 28 different chemical fertilizer treatments. The effects of long-term use of chemical fertilizer on SOC pool provide a credible basis to accurately estimate the SOC pool and SCS in the HHH. The data presented indicate that higher application rates of $\mathrm{N}$ fertilizer enhance the $\mathrm{SOC}_{\mathrm{s}}$ in the HHH of China [27, 30].

application; f. Mean for the different categories of CK, N, NP, NPK, $\mathrm{P}, \mathrm{NK}, \mathrm{PK}$ across the HHH. The mean for different treatments in $\mathrm{X}$ axis is the same as Tables 1 and 2. Mean followed by lower difference letter differ from one another at $5 \%$ level of probability for different treatments within the same categories, the capital difference letter for the different categories

\section{Effects of Chemical Fertilizer Managements on SOC} Pool Compared with CK

The $\mathrm{SOC}_{\operatorname{Tr}}$ pool for different fertilizer treatments was computed but using the corresponding CK treatment as baseline to understand possible mechanisms of change in SOC pool (Fig. 4). Any change in SOC pool is the net result of input and output. For the chemical fertilizer treatments without application of organic manure, input of $\mathrm{C}$ were those from roots, root exudates, and straw. The input from below-ground root biomass is important. The research data about the rate of root and shoot biomass production and input are important to assess the net impact 
on SOC pool. The root:shoot ratio is strongly impacted by the availability of plant nutrients (i.e., N, P, K). Accordingly, the data show that the SOC pool was in the order of $\mathrm{NPK}>\mathrm{NP}>\mathrm{N}>\mathrm{CK}$ across the HHH. Further, The SOC pool increased with application of $\mathrm{P}$ and with increase in the rate of $\mathrm{N}$ use. However, the maximum increase in SOC pool was observed for the combined use of NPK fertilizer. These results are similar to those reported by Kukal et al. [20], who observed that the total above-ground biomass production was much more with integrated (NPK) nutrients management than that with unbalanced use of N, P, and NP fertilizer.

The HHH has a long history of cultivation, and soil fertility declined due to the low fertilizer inputs from 1960 to 1980 [24]. These trends in SOC pool in cropland soils of the $\mathrm{HHH}$ ecosystem are similar to those of cultivated soils of South Asia and Sub-Saharan Africa where the decline in SOC pool has caused an attendant decline in soil quality [22, 23]. Long-term use of extractive farming practices without fertilizer input and using crop residues as fuel exacerbated the decline of soil fertility across the $\mathrm{HHH}$. Application of $\mathrm{N}, \mathrm{P}$ alone or combined $\mathrm{N}, \mathrm{P}$, and $\mathrm{K}$ greatly improved crop yields along with the high amount of root biomass added to the soils. The high amount of roots and root exudates increased with the increase in SOC pool and also improved soil fertility even without the use of any organic fertilizer inputs. Consequently, the rates of application of $\mathrm{N}$ and $\mathrm{P}$ fertilizer have increased in the entire $\mathrm{HHH}$. These studies indicate the reason of increase in the SOC pool from 1980s to 2000s in cropland soils of China $[13,31]$.

Regression equations depicting change in SOC pool with increase in application rate of $\mathrm{N}$ and $\mathrm{P}$ use for $\mathrm{N}$ and
NP fertilizer management treatments compared with CK for the experimental period are shown in Fig. 5. There was a linear trend of increase in SOC pool with increase in $\mathrm{N}, \mathrm{P}$, and NP land uses and management treatments. The SOC pool was greatly enhanced by the increase in application rate of $\mathrm{N}$ and $\mathrm{P}$ fertilizers.

The effects of long-term application of chemical fertilizer on SOC pool among eight experimental sites in the HHH substantiate the hypothesis that the high application rates of chemical fertilizer is an important strategy to improve soil fertility and meet the demands for wheat and maize. The data presented indicate that SOC sequestration potential strongly depends on the type (formulation) and rates of fertilizer use in the $\mathrm{HHH}$. The linear increase in the SOC pool with increase in the application rates of $\mathrm{N}$ and $\mathrm{P}$ fertilizer provides a reliable basis for obtaining accurate estimates of SOC pool across the entire $\mathrm{HHH}$.

\section{Effects of Long-Term Chemical Fertilizer Management on SOC Pool}

Changes in SOC pool with reference to the antecedent as baseline pool were also computed to understand different mechanisms in relation to experimental duration. Of all the 28 chemical fertilizer treatments, the SOC pool increased in 7 treatments and decreased in 21 treatments over times. The magnitude of decrease in SOC pool ranged from $-1.5 \mathrm{Mg} \mathrm{ha}^{-1}$ in $\mathrm{N} 2$ to $-0.2 \mathrm{Mg} \mathrm{ha}^{-1}$ in PK treatment. In comparison, the magnitude of increase in SOC pool ranged from $0.2 \mathrm{Mg} \mathrm{ha}^{-1}$ in N5P6 to $1.9 \mathrm{Mg} \mathrm{ha}^{-1}$ in N5P6K3 treatment. The SOC pool decreased among all categories but for the $\mathrm{P}$ treatments (Fig. 6). This trend indicates that the antecedent SOC pool was more than the finial pool after
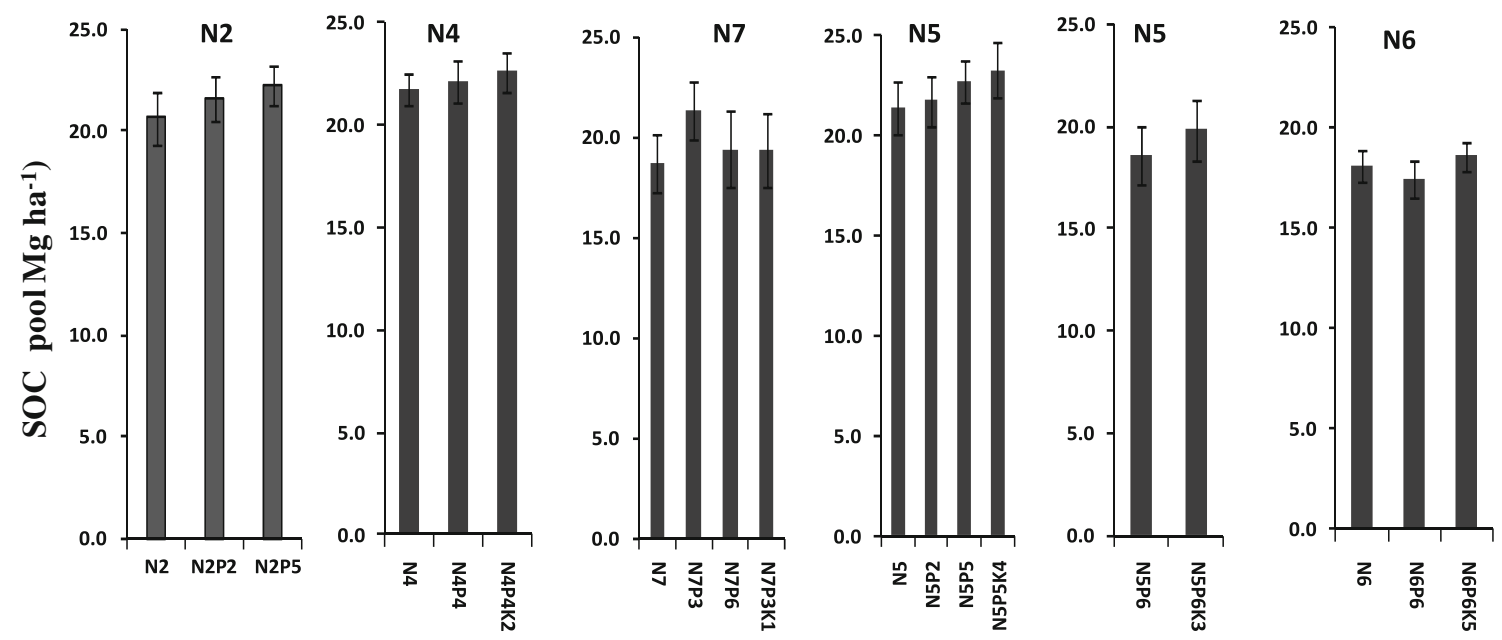

Treatments

Fig. 3 Effects of N, P, K at the same rate of $\mathrm{N}$ chemical fertilizer on SOC pool. There are different treatments including 6 rates of $\mathrm{N}$ application, and the corresponding different rates of $\mathrm{P}, \mathrm{K}$ combined the different rates of $\mathrm{N}$ across the whole HHH. Increase in SOC with increase in different rates of $\mathrm{P}$ or $\mathrm{K}$ at the same rates of $\mathrm{N}$ application 

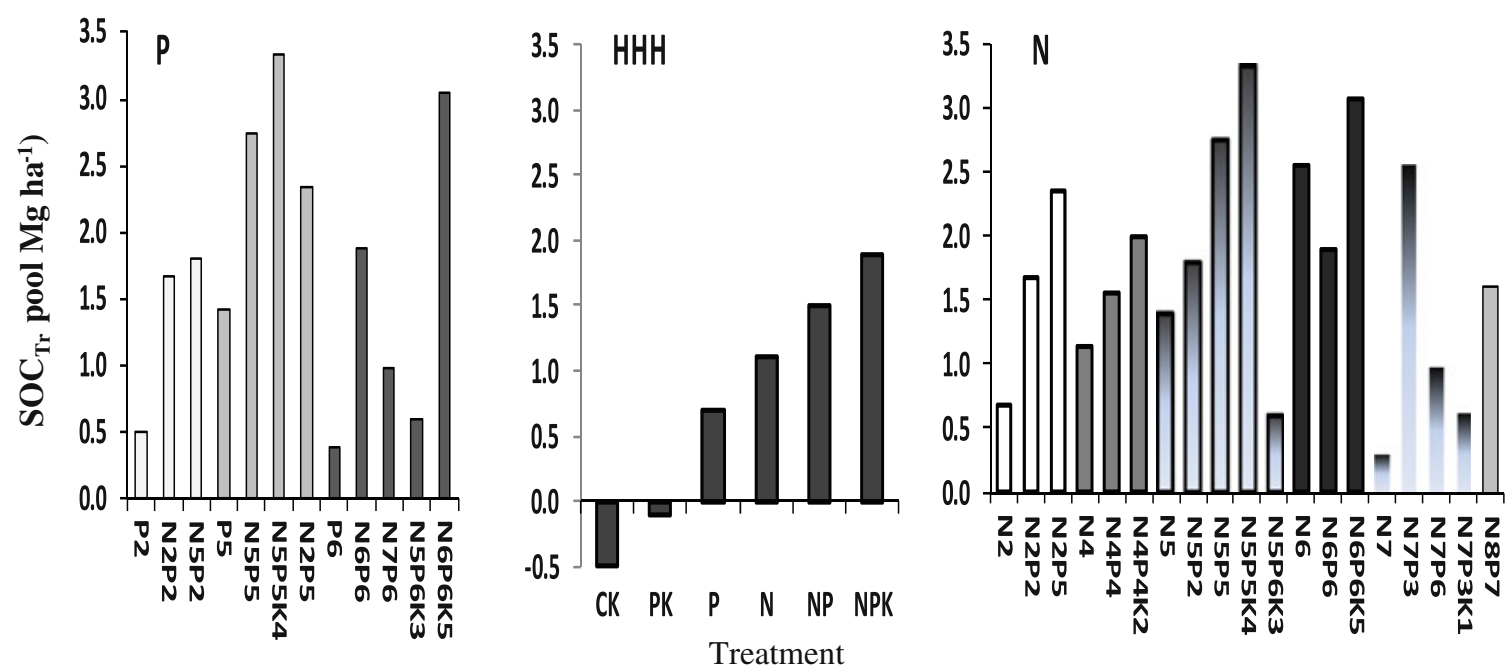

Fig. 4 Increase in SOC pool with increase in rates of N, P, K and the combination of N, P, K compared with CK
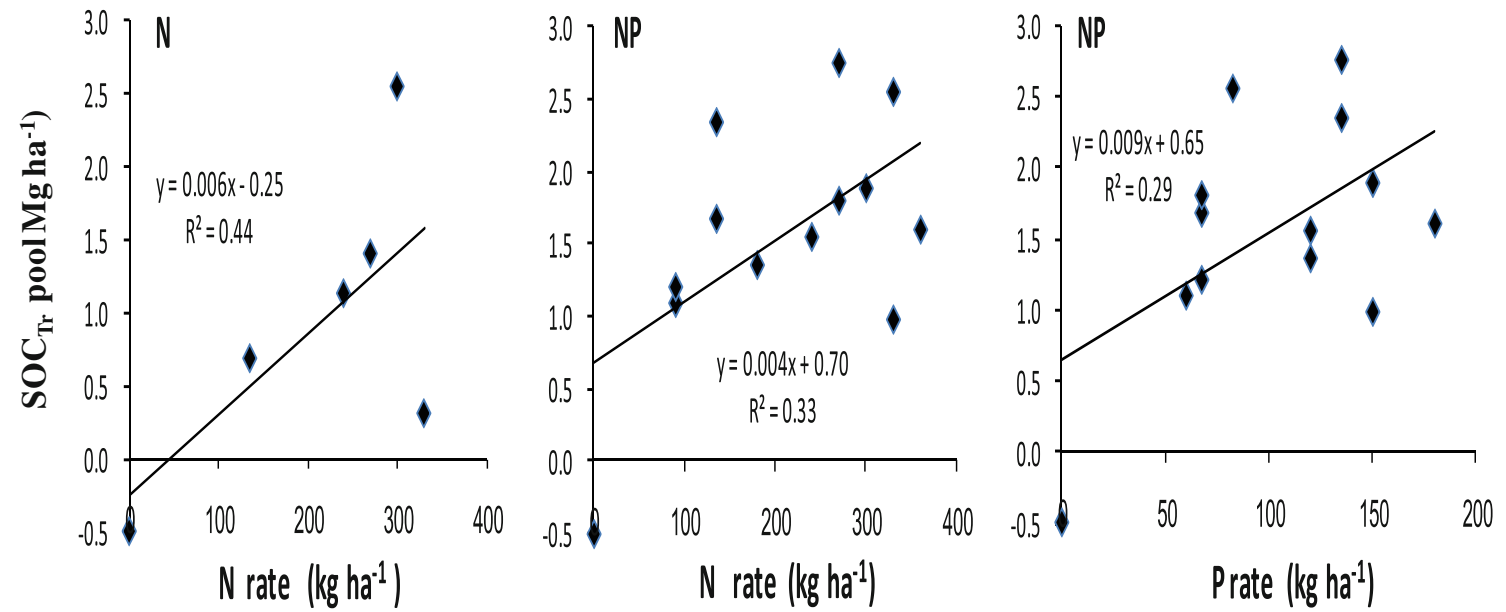

Fig. 5 Increase in SOC pool with increase in $\mathrm{N}, \mathrm{P}$ chemical fertilizer rate at the rates of $\mathrm{N}$ application compared with $\mathrm{CK}$

23 years of cultivation. The SOC pool decreased over time under the same application rate of chemical fertilizer. Thus, the rate of the chemical fertilizers use is a strong determinant of the SOC pool in croplands.

The regression equations relating SOC pool to time for different application rates of $\mathrm{N}$ and $\mathrm{P}$ fertilizer are shown in Fig. 7. There was a linear trend of increase in SOC pool with increase in the rates of $\mathrm{N}$ and $\mathrm{P}$ use for $\mathrm{N}, \mathrm{NP}$, and NPK fertilizer management treatments. Although, the magnitude of SOC pool is determined by the antecedent value and the cultivation duration, the SOC pool increased with increase in application rates of fertilizer. Combined application of $\mathrm{N}, \mathrm{P}$, and $\mathrm{K}$ and the higher application rates are necessary to enhancing the SOC pool. Thus, land managers have adopted higher rates of fertilizer use in general [18], and specially in the $\mathrm{HHH}[4,10]$.
The Rate of Change of SOC Pool under Diverse Chemical Fertilizer Management

Of the total of 36 treatments involving 28 diverse chemical fertilizer managements at eight long-term experimental sites, increase in SOC pool was observed in 9 treatments (25\%) and decrease in 19 treatments $(75 \%)$. The steady rate $(\mathrm{SR})$ and average rate (AR) of change in SOC pool among treatments shown in Fig. 8 indicate that the AR of change in SOC pool was -250.0 to $270 \mathrm{~kg} \mathrm{ha}^{-1}$ year $^{-1}$, and the SR of change was -253 to $142 \mathrm{~kg} \mathrm{ha}^{-1}$ year $^{-1}$. The SOC pool declined with the chemical fertilizer management except for N7, N7P6, N8P7, N5P6K3, and N6 treatments. This rate of $\mathrm{N}, \mathrm{P}$, and $\mathrm{K}$ fertilizer is the threshold value for increasing the SOC pool with chemical fertilizer management in the $\mathrm{HHH}$. Increase by $3.7 \mathrm{Mg} \mathrm{C}^{-1}$ in NPK, but 


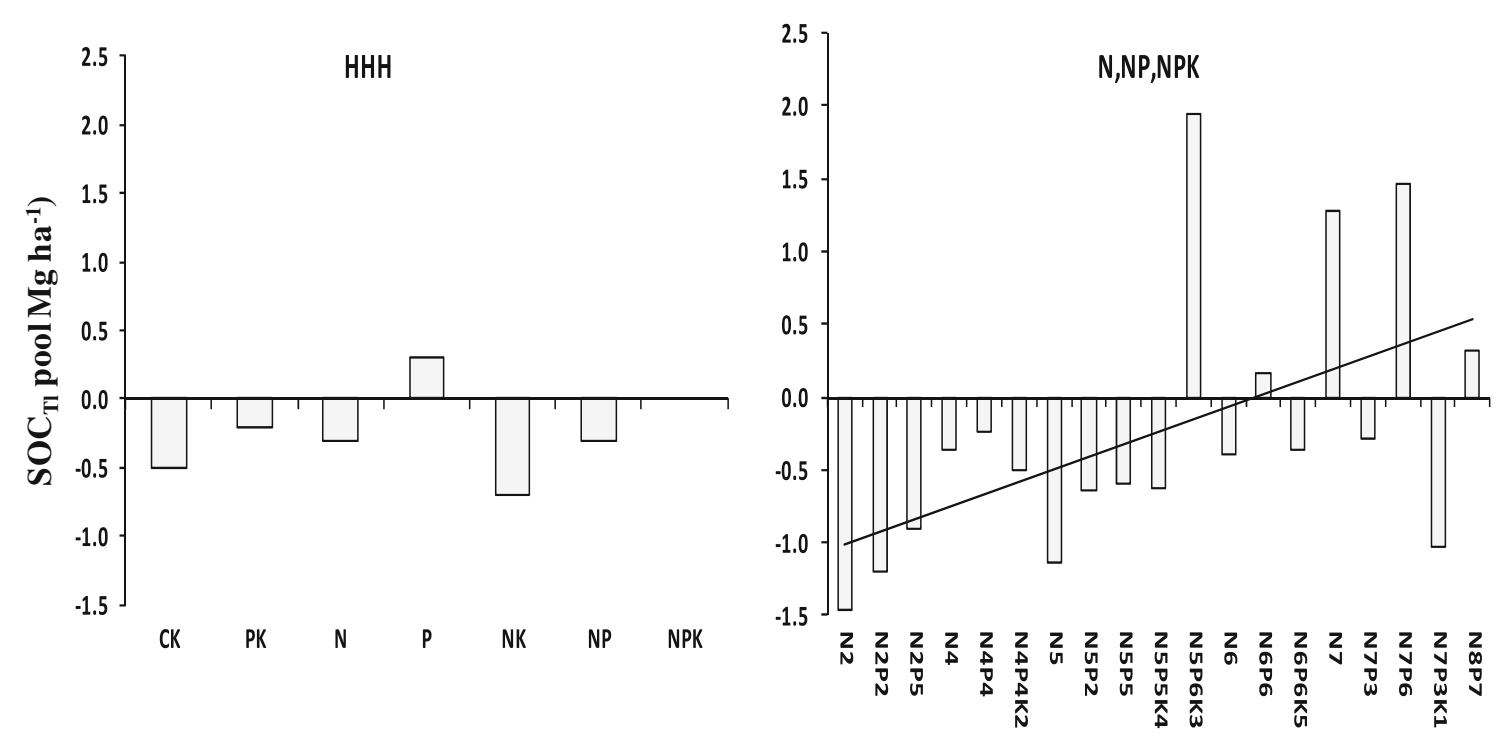

Fig. 6 Change in SOC pool over the experimental period compared with the antecedent pool in different treatments
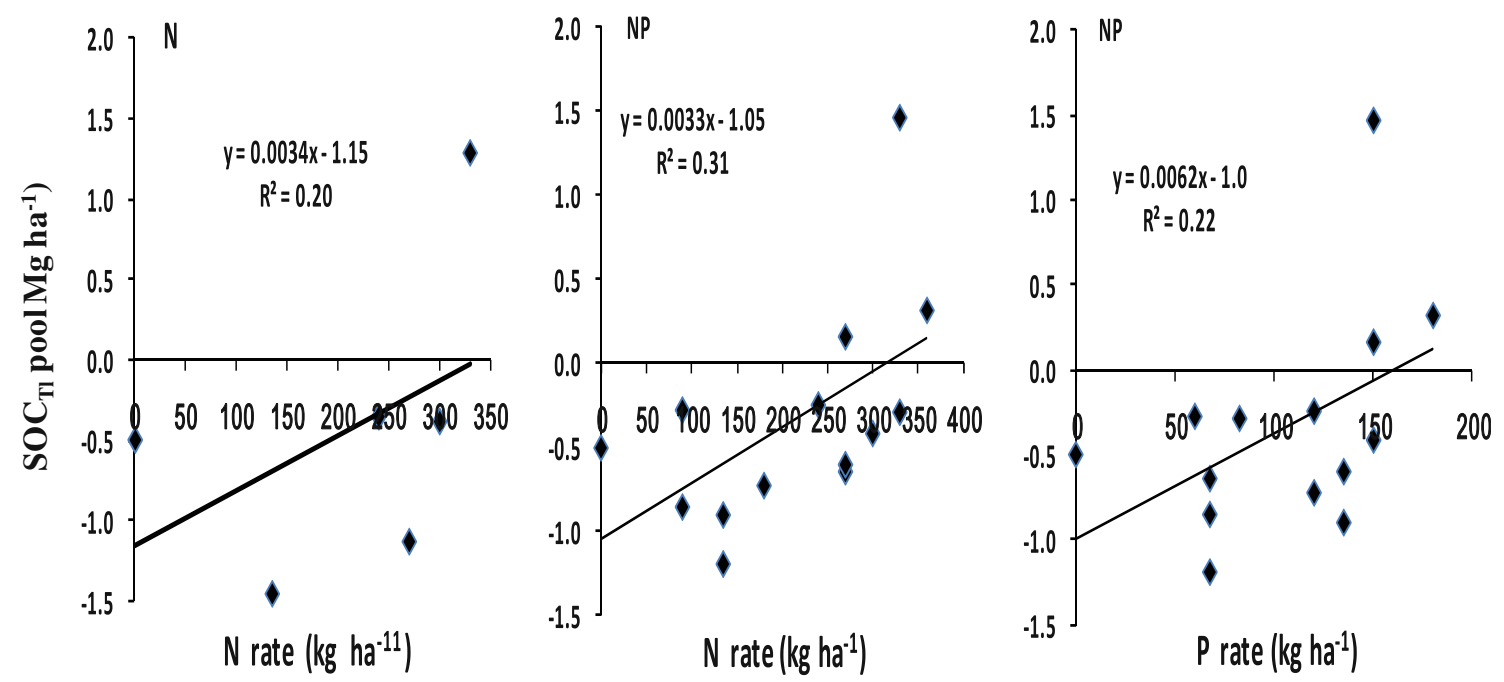

Fig. 7 Increase in SOC pool with increase in N, P rates for all the treatments compared with antecedent SOC value

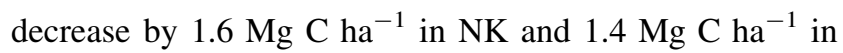
CK for SOC pool over 14 years (1990-2003) was reported in Fengqiu in HHH (2). Increase in SOC pool by continuous application of fertilizers in NPK over the initial baseline content was also reported in India [33].

These data present indicate that a suitable treatment for sustainable management of SOC pool was NPK. The threshold of application rates of chemical fertilizer for increasing the SOC pool was 270 for $\mathrm{N}, 150$ for $\mathrm{P}$, and $150 \mathrm{~g} \mathrm{ha}^{-1}$ for $\mathrm{K}$. The rate of chemical fertilizer can substantially increase the SOC pool and also sustain it at a higher level of $40 \mathrm{Mg} \mathrm{C}^{-1}$ in the $\mathrm{HHH}$. Using these experimental rates of change in SOC pool for 36 diverse treatments can provide accurate estimation of SOC pool and sequestration rate in the $\mathrm{HHH}$.

\section{Discussions}

The data presented show the effects of different fertilizer management on the SOC pool for the $0-20 \mathrm{~cm}$ only. The diversity rates of SOC pool in this article give the specific basis for calculating SOC pool under different fertilizer managements under different soils and climates in the HHH region. However, if we want to find the mechanism of soil carbon sequestration in detail in this region, the balance $\mathrm{C}$ on the basis of input and output should be further studied, because soil carbon pool is strongly affected by net primary productivity, texture (clay content) [19], and temperature and rainfall.

Linking agricultural nutrient system with economic development indicated that the agricultural pool has been depleted in cropland soils of many developing countries 


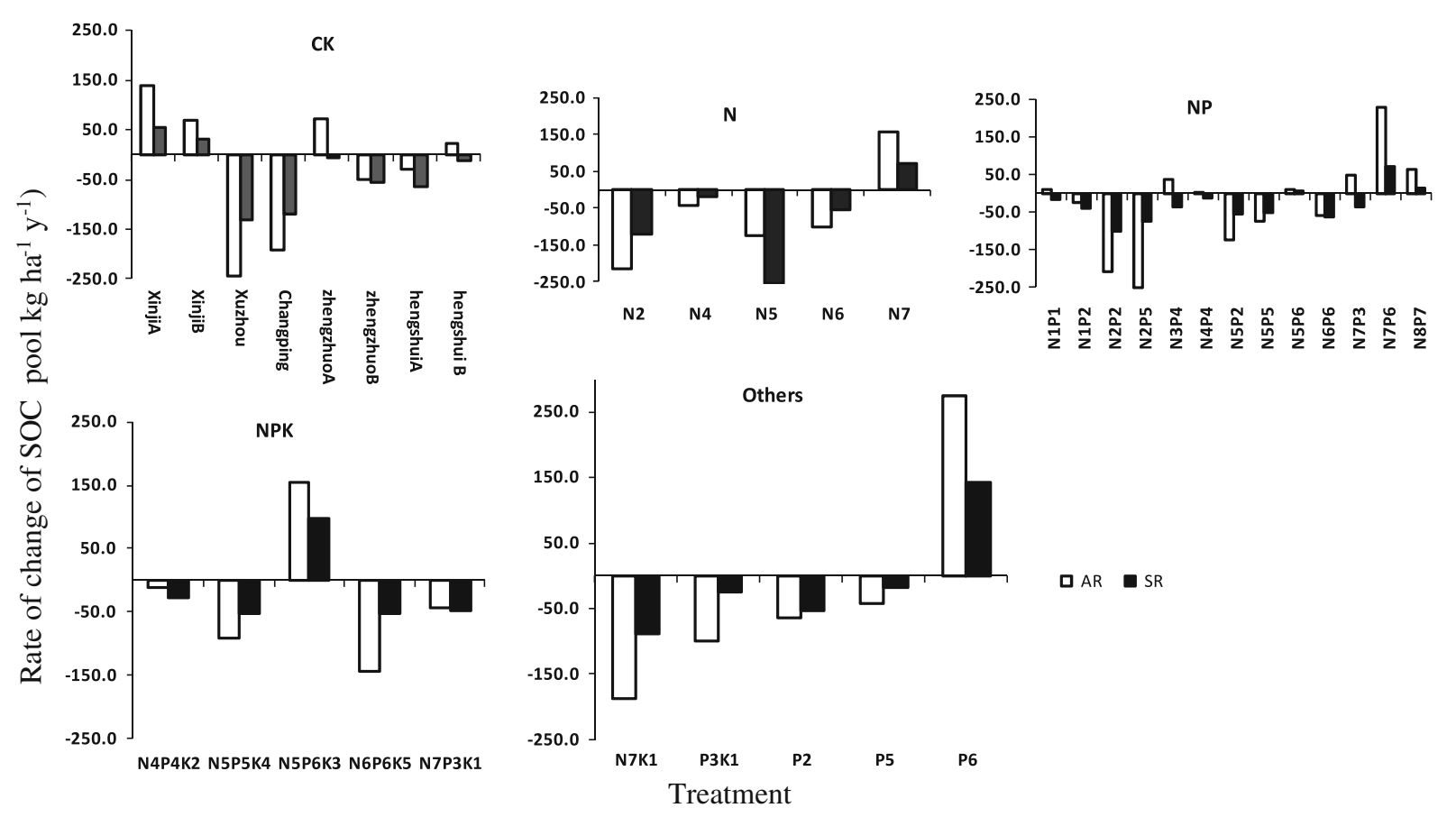

Fig. 8 Rate of change of SOC pool for different treatments across the HHH region over time

(19), particularly those in sub-Saharan Africa (20). The reason is the low inputs of nutrients that are inadequate to maintain soil fertility. However, nutrients harvested must be replaced to ensure food security [21]. The data presented show that an integrated and balanced application of fertilizers composed of $\mathrm{N}, \mathrm{P}, \mathrm{K}$ in China not only ensured its food security, but also increased SOC pool in major farmlands except for Northeast China [30].

These data show a linear increasing trend between SOC pool and the application rates of $\mathrm{N}$ fertilizer in different soil types in the HHH region. The SOC pool (and soil quality) in the $\mathrm{HHH}$ is relatively lower than that in northern and southern China [30]. However, only the application of combined N, P, and $\mathrm{K}$ can enhance SOC pool to the high level.

The sustainable fertilizer management, similar to those of NPK, can restore the SOC stock to above the threshold level and also improve crop yields. Therefore, integrated chemical fertilizer $\mathrm{N}, \mathrm{P}$, and $\mathrm{K}$ management (NPK) is the best choice for the developing countries to advancing food security while mitigating climate change.

\section{Conclusions}

Experimental data based on 36 treatments implemented at eight different long-term field experimental sites in the HHH support the following conclusions.

The SOC pool was in the order of NPK $>\mathrm{N}>\mathrm{NP}>$ $\mathrm{NK}>\mathrm{P}>\mathrm{PK}>\mathrm{CK}$, and the best treatments was NPK for increasing the SOC pool in $\mathrm{HHH}$.
Although SOC pool is determined by the antecedent baseline value and the experimental duration, higher application rates of $\mathrm{N}, \mathrm{P}$ and combined chemical fertilizer can increase SOC pool to a higher level. There was a linear increase in SOC pool with increase in the rate of $\mathrm{N}$ fertilizer used either alone or in combination with $\mathrm{P}$. The threshold application rates of chemical fertilizer in treatment of NPK for increasing the SOC pool was 270 for N, 150 for $\mathrm{P}$, and $150 \mathrm{~kg} \mathrm{ha}^{-1}$ for $\mathrm{K}$. The rate of chemical fertilizer can substantially increase the SOC pool and also sustain it at a higher level of $40 \mathrm{Mg} \mathrm{Cha}^{-1}$ in $\mathrm{HHH}$.

The rate of change of SOC pool was -250.0 to $270 \mathrm{~kg} \mathrm{ha}^{-1}$ year $^{-1}$ for AR and -253 to $142 \mathrm{~kg} \mathrm{ha}^{-1}$ year $^{-1}$ for SR. The threshold rate of chemical fertilizer for increasing the SOC pool was 270 for N, 150 for P, and $150 \mathrm{~kg} \mathrm{ha}^{-1}$ for K.

The experimental data on SOC pool, SOC sequestration, and the rate of change for 36 diverse treatments provide a credible basis for estimation of SOC pool and the rate of SOC sequestration in the HHH. Thus, judicious use of chemical fertilizer is an important strategy to enhance SOC sequestration and sustain high crop production across the HHH of China.

Acknowledgments This work was supported by the National Natural Science Foundation of China (Grant No. 40871254).

\section{References}

1. Alvarez R (2005) A review of nitrogen fertilizer and conservation tillage effects on soil organic carbon storage. Soil Use Manag 21:38-52 
2. Cai ZC, Qin SW (2006) Dynamics of crop yields and soil organic carbon in a long-term fertilization experiment in the Huang-HuaiHai Plain of China. Geoderma 136:708-715

3. Cao CF, Kong LC, Wang ZS et al (2003) Effect of long-term trial on raising fertility of Shajiang Black Soil (in Chinese). Chin J Soil Sci 34:102-105

4. Chen XP, Cui ZL, Vitousek PM et al (2011) Integrated soil-crop system management for food security. www.pnas.org/cgi/doi/10. 1073/pnas.1101419108

5. Deng XZ, Jian GQ, Lin YZ, Han JZ (2010) Simulation of the changes of soil organic carbon pool of cropland in China (in Chinese). Geogr Res 29(11):94-100

6. Fang QX, Ma L, Green TR, Yu Q, Wang TD, Ahuja LR (2010) Water resources and water use efficiency in the North China Plain: current status and agronomic management options. Agric Water Manag 97:1102-1116

7. Gee GW, Bauder JW (1986) Particle-size analysis. In: Klute A (ed) Methods of soil analysis. American Society of Agronomy/ Soil Science Society of America, Madison, pp 383-411

8. Gong W, Yan XY, Wang JY, Hu TX, Gong YB (2009) Longterm manuring and fertilization effects on soil organic carbon pools under a wheat-maize cropping system in North China Plain. Plant Soil J 314:7-67

9. Guo LP, Zhang FS, Wang XR et al (1998) Effect of different fertilizer management on mineral nitrogen in Fluvo-aquic soil. J China Agric Univ (Chinese) 3(a):54-61

10. Guo JH, Liu XJ, Zhang Y, Shen JL (2010) Significant acidification in major Chinese croplands. Science 327:1008

11. Harris D (2004) Water and nitrogen management in wheat-maize production on the north China plain. www.aciar.gov.au

12. HJ Lei, BJ Li, Bai YL, Huang YF, KJ Li (2005) Estimation of soil organic matter mineralization in the plough layer and $\mathrm{CO} 2$ emission under different farming practices in China's HuangHuai-Hai plain (in Chinese). Scientia Agricultura Sinica 38(5):956-964

13. Huang Y, Sun WJ (2006) The soil C distribution change from 1980 to 2000 in China. Sci Press 51:750-752

14. Huang B, Wang JG, Jin HY et al (2006) Effects of long-term application fertilizer on carbon storage in Calcareous Meadow Soil (in Chinese). Agro-Environ Sci 25:161-164

15. Huang S, Peng XX, Huang QR, Zhang WJ (2010) Soil aggregation and organic carbon fractions affected by long-term fertilization in a red soil of subtropical China. Geoderma 154:364-369

16. Jin SL, Ma YT (1995) A preliminery study on effects of long term different fertilization on crop yield and soil nutrients (in Chinese). Gansu Agric Sci Tech 6:23-25

17. Kaur T, Brar BS, Dhillon NS (2008) Soil organic matter dynamics as affected by long-term use of organic and inorganic fertilizers under maize-wheat cropping system. Nutr Cycl Agroecosyst 81:59-69

18. Kong XB, Zhang FR, Qi W (2006) Influence of land use change on soil nutrients in an intensive agricultural region of North China. Soil Tillage Res 88:85-94

19. Kong XB, Dao TH, Qin J, Qin HY, Li CZ, Zhang FR (2009) Effects of soil texture and land use interactions on organic carbon in soils in North China cities' urban fringe. Geoderma 154:86-92

20. Kukal SS, Rasool R, Benbi DK (2009) Soil organic carbon sequestration in relation to organic and inorganic fertilization in rice-wheat and maize-wheat systems. Soil Tillage Res 102:87-92

21. Lal R (2004) Soil carbon sequestration impacts on global climate change and food security. Science 304:1623-1627

22. Lal R (2010) Enhancing eco-efficiency in agro-ecosystems through soil carbon sequestration. Crop Sci 50:120-121

23. Lal R (2010) Beyond Copenhagen: mitigating climate change and achieving food security through soil carbon sequestration. Food Secur 2:169-177
24. Lei HJ (2005b) Dynamic modeling for soil organic carbon and its application under intensive cropping systems in the Huang-Huai-Hai plain of China (in Chinese). China Agricultural University, Beijing

25. Li ZP, Han FX, Su Y, Zhang TL, Monts DL, Sun B, Plodinec MJ (2007) Assessment of soil organic and carbonate carbon storage in China. Geoderma 138:119-126

26. Lin ZA, Zhao BQ, Yuan L (2009) Effects of organic manure and fertilizers long-term located application on soil fertility and crop yield. Scientia Agricultura Sinica (Chinese) 42(8):2809-2819

27. Lu F, Wang XK, Han B, Yun Zh (2009) Soil carbon sequestrations by nitrogen fertilizer application, straw return and no-tillage in China's cropland. Glob Change Biol 15:281-305

28. Ma JY, Cao CY, Zhang C, Li KJ, Ren TS (2010) Effect of longterm application of chemical fertilizers and organic manure on soil organic carbon and bulk density (in Chinese). China Soil Fertilizer 6:38-40

29. Pan GX, Li LQ, Wu LS, Zhang XH (2003) Storage and sequestration potential of topsoil organic carbon in China's paddy soil. Glob Change Biol 10:79-92

30. Pan GX, Xu XW, Smith P, Lal R (2010) An increase in topsoil SOC pool of China's croplands between 1985 and 2006 revealed by soil monitoring. Agric Ecosyst Environ 136:133-138

31. Piao SL, Fang JY, Ciais P, Peylin P, Huang Y (2009) The carbon balance of terrestrial ecosystems in China. Nature 458:10091010

32. Qiu JJ, Wang LG, Li H, Tang HJ, Li CS (2009) Modeling the impacts of soil organic carbon content of croplands on crop yields in China. Agric Sci China 8(4):464-471

33. Soil Survey Staff (1999) Soil taxonomy. A basic system of soil classification for making and interpreting soil surveys, 2nd edn. USDA Natural Resources Conservation Service Agricultural Handbook, vol 436. US Government Printing Office, Washington, DC

34. Tiessen H, Moir JO (1993) Total and organic carbon. In: Carter MR (Ed) Soil sampling and methods of analysis. Lewis Publishers, Boca Raton, pp 187-199

35. Wang LG, Qiu JJ, Tang HJ, Li H, Li CS, Ranst EV (2008) Modelling soil organic carbon dynamics in the major agricultural regions of China. Geoderma 147:47-55

36. Wang CJ, Pan GX, Tian YG, Li LQ, Zhang XH, Han XJ (2010) Changes in cropland topsoil organic carbon with different fertilizations under long-term agro-ecosystem experiments across mainland China. Sci China 53(7):858-867

37. Wu LZ, Cai ZC (2007) Estimation of the change of topsoil organic carbon of croplands in China based on long-term experimental data. Ecol Environ 16(6):1768-1774

38. Xia WJ (2007) Effect of long-term fertilization on soli physical, chemical and biological characteristics in the Calcareous FluvoAquic soil (Chinese). Dissertation, Chinese Academy of Agricultural Sciences, Beijing, pp 10-12

39. Xia WJ, Liang GQ, Zhou W (2008) A adsorption and desorption characteristics of soil phosphorus in calcareous in fluvo-aquic soil under long-term fertilization (Chinese). Plant Nutr Fertilizer Sci 14(3):431-438

40. Yu GR, Fang HJ, Gao LP, Zhang WJ (2006) Soil organic carbon budget and fertility variation of black soils in Northeast China. Ecol Res 21:855-867

41. Yu DS, Shi XZ, Wang HJ, Sun WX, Chen JM, Liu QH, Zhao YC (2007) Regional patterns of soil organic carbon pools in China. J Environ Manage 85:680-689

42. Zhang AJ, Zhang MP (2002) Study on regularity of growth and decline of soil organic matter under long-term fertilization for yellow fluvo-aquic soil (in Chinese). J Anhui Agric Univ 29(1):60-63

43. Zhang H, Chen BD, Huang XR (2002) Study of fertilization on variations of soil nutrients and environmental quality with long- 
term location field experiment in Chao Soil. Effect of fertilization on dynamics changes of $\mathrm{NO}_{3}-\mathrm{N}$ in soil profile (Chinese). Chin $\mathrm{J}$ Soil Sci 33(1):28-29
44. Zhang YG, Liu HB, Li ZH (2005) Study of nitrate leaching potential from agricultural land in Northern China under long-term fertilization conditions (Chinese). Plant Nutr Fertilizer Sci 11(6):711-716 